\title{
RENCANA KAMPUNG TEMATIK KELURAHAN CIKARET KOTA BOGOR BERBASIS KOMUNITAS
}

\author{
Rahmat Rejoni ${ }^{1}$, Andrianto Kusumoarto ${ }^{2}$ \\ ${ }^{1}$ Universitas Indraprasta PGRI, Program Studi Arsitektur \\ rahmat.rejoni@gmail.com \\ ${ }^{2}$ Universitas Indraprasta PGRI, Program Studi Arsitektur \\ andrianto.kusumoarto@unindra.ac.id
}

\begin{abstract}
One of the areas and spaces in a city is the urban village area which is located almost spread in all urban areas and is generally dominated by residential areas with generally high settlement densities. This area is an inseparable part of an urban area and its physical form and order must be harmonized with the city, and at the same time it must also have a level of community welfare that is also in harmony and can support the level of welfare of the city. In order to improve the quality of society and the environment in Bogor City as desired by the Bogor City government, in 2017 an innovative thematic village idea contest was held. In order to implement the results of this innovative thematic village idea competition, a Landscape Design Plan for 7 (seven) villages with the highest value was carried out. One of them is KAMPUNG SEMUT KROTO Area, Cikaret Village, South Bogor District. Through the program of community service activities Indraprasta University PGRI Jakarta Faculty of Computer Science Engineering Department majoring in Architecture will collaborate with the village of Cikaret to organize the thematic tourist village. Community service with thematic village planning in the Cikaret sub-district will offer solutions to make Thematic village design concept drafts and make Thematic village design engineering details.
\end{abstract}

Key Words: site planning, community park, social park

\begin{abstract}
Abstrak. Salah satu kawasan dan ruang dalam suatu kota adalah kawasan kampung kota yang letaknya hampir tersebar di semua wilayah perkotaan dan umumnya didominasi oleh kawasan hunian dengan kepadatan permukiman yang umumnya tinggi. Kawasan ini merupakan bagian yang tidak terpisahkan dari suatu wilayah perkotaan dan harus diselaraskan bentuk dan tatanan fisiknya dengan kota tersebut, dan pada saat yang bersamaan juga harus memiliki tingkat kesejahteraan masyarakat yang juga selaras dan dapat mendukung tingkat kesejahteraan kota. Dalam rangka peningkatan kualitas masyarakat dan lingkungan di Kota Bogor seperti yang diinginkan oleh pemerintah Kota Bogor, pada tahun 2017 diadakan perlombaan gagasan kampung tematik yang inovatif. Guna mengimplementasikan hasil dari perlombaan gagasan kampung tematik yang inovatif ini maka dilakukan penyusunan Rancang Lanskap 7 (tujuh) kampung yang memiliki nilai tertinggi. Salah satunya yaitu Kawasan KAMPUNG SEMUT KROTO Kelurahan Cikaret, Kecamatan Bogor Selatan. Melalui program kegiatan pengabdian masyarakat Universitas Indraprasta PGRI Jakarta Fakultas Teknik Ilmu Komputer jurusan Arsitektur akan mengadakan kerjasama dengan kelurahan cikaret untuk melakukan penataan Kampung wisata tematik tersebut. Pengabdian masyarakat dengan perencanaan kampung tematik di kelurahan Cikaret, akan menawarkan solusi Membuat Konsep desain kampung tematik kelurahan dan membuat Detail engineering desain kampung tematik.
\end{abstract}

Kata Kunci : Kampung tematik, kota, lanskap, semut kroto

\section{PENDAHULUAN}

Pembangunan suatu kota adalah satu model pembangunan yang menyeluruh, baik dalam keteraturan dan modernisasi dari ruang-ruang kota, dan juga untuk meningkatkan kesejahteraan dan kualitas semua warga kota yang menghuninya.

Selain pembangunan pada Kawasan pusatpusat perdagangan, pembangunan di kota juga perlu ditingkatkan pada ruang-ruang public dan ruang kehidupan dari seluruh lapisan masyarakat. Salah satu kawasan dan ruang dalam suatu kota adalah kawasan kampung kota yang letaknya hampir tersebar di semua wilayah perkotaan dan umumnya didominasi oleh kawasan hunian dengan kepadatan permukiman yang umumnya tinggi. 
Dalam rangka peningkatan kualitas masyarakat dan lingkungan di Kota Bogor seperti yang diinginkan oleh pemerintah Kota Bogor, pada tahun 2017 (BAPPEDA, 2017) diadakan perlombaan gagasan kampung tematik yang inovatif. Guna mengimplementasikan hasil dari perlombaan gagasan kampung tematik yang inovatif ini maka dilakukan penyusunan Rancang Lanskap 7 (tujuh) kampung yang memiliki nilai tertinggi. Salah satunya yaitu "Kawasan Kampung Kelurahan Cikaret, Kecamatan Bogor Selatan.

Adapun tema yang diambil pada kampung tematik tersebut adalah Kampung Semut Kroto, hal ini dikarenakan di dalam kampung tersebut terdapat usaha produksi semut kroto sebagai produsen umpan pancing yang selama ini dikeluhkan oleh para pemacing karena kesulitan untuk mendapatkan kroto sebagai bahan umpan pancing (gambar 1).
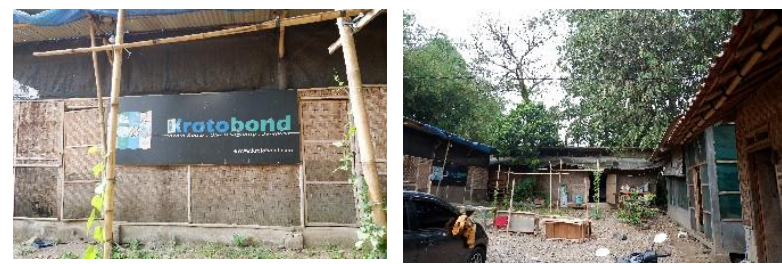

Gambar 1. Kondisi usaha kroto bond

Semut adalah serangga yang tergabung dalam Ordo Hymenoptera seperti halnya lebah atau tawon. Semut rangrang (Oechophylla smaragdina) masuk dalam famili Formicidae. Semut rangrang yang dahulunya umumnya dianggap mengganggu manusia dan tanaman tetapi akhir-akhir ini, telur semut atau krotonya juga dicari oleh banyak orang untuk menjadi umpan pancing ikan dan juga makanan burung berkicau karena kroto ini memiliki kandungan protein yang tinggi. Koloni semut ini disebut sebagai "Superorganisme" karena pada tiap koloni-koloni mereka membentuk sebuah kesatuan (InfoAgribisnis.com, 2017).

Dikampung tersebut terdapat bududaya semut kroto yang kondisinya sudah sangat memprihatinkan lokasi berada di Jl. Kapten Yusuf Jl. Raden Kosasih No.3, RT.02/RW.08, Cikaret, Kec. Bogor Sel., Kota Bogor, Jawa. Disekitar site terdapat beberapa vegetasi tanaman dengan tingkatan strata yang berbeda-beda, kondisi jalan utama masih bagus, namun terdapat jalan yang rusak disekitar kawasan permukiman (gambar 2).
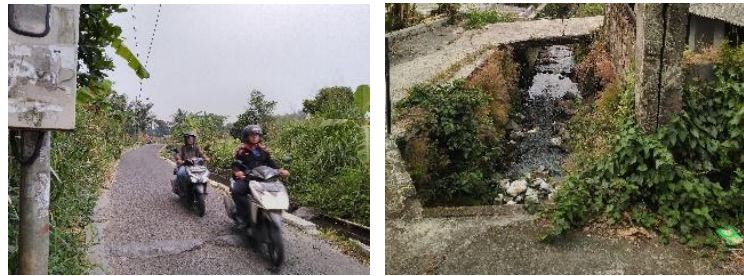

Gambar 2. Kondisi jalan dan lingkungan

Rencana kampung ini akan dikembangkan dengan memperhatikan nilai-nilai pemberdayaan masyarakat dan kelestarian lingkungan. Dengan tujuan untuk menjalankan usaha berbasis pemberdayaan masyarakat yang diharapkan dapat berdampak terhadap penurunan tingkat pengangguran, juga agar tercipta masyarakat yang mandiri.

\section{METODOLOGI}

Kegiatan perencanaan kampung tematik di Kota Bogor dimulai pada tanggal 11 November 2019 hingga 29 Februari 2020. Dalam waktu yang telah ditetapkan oleh Bidang Pertamanan, PJU dan Dekorasi Kota, Dinas Perumahan dan Permukiman, Kota Bogor, dan Kelurahan Cikaret. Metode yang digunakan adalah metode kualitatif dengan pendekatan desain berbasis komunitas (community based design) yang memadukan metode (Hester, R. T., 1990), (Booth, 1990), dan (Motloch, 2001) dalam (Kusumoarto \& Librianti, 2018). Dengan Tahapan sebagai berikut 1) melakukan diskusi penetapan lokasi dengan Bidang Pertamanan, PJU, dan Dekorasi Kota, Pemerintah Kota Bogor, dan Kelurahan Cikaret 2) Peninjauan lokasi perencanaan dan desain dengan Bidang Pertamanan, PJU dan Dekorasi Kota, Pemerintah Kota Bogor, dan Pihak Kelurahan Cikaret 3) inventarisasi kondisi, luas dan letak lokasi; 4) identifikasi biofisik lokasi; 5) diskusi dengan instansi pemerintah dan masyarakat untuk mendapatkan persepsi dan keinginannya; 6) identifikasi pola prilaku penggunaan lokasi; 7) analisis tapak; 8) konsep pengembangan tapak; 9) rencana tapak; 8) desain pengembangan tapak. 


\section{HASIL DAN PEMBAHASAN}

\section{Lokasi Kegiatan}

Lokasi deliniasi kegiatan Kampung Tematik berada di sebagian RW 08, RW 12 dan RW 07 Kelurahan Katulampa dengan luas 4,32 Ha (gambar 3).

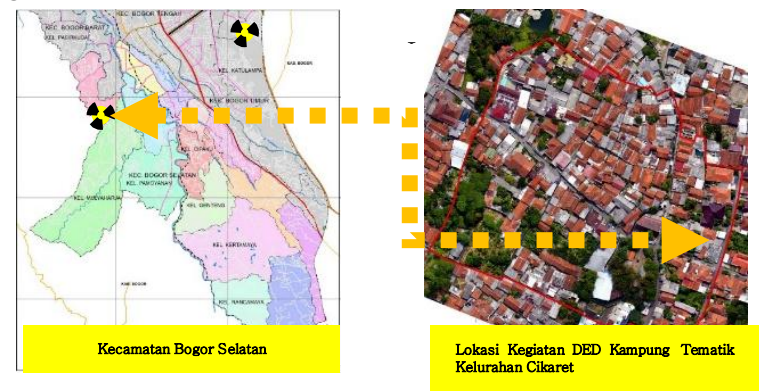

Gambar 3. Lokasi kegiatan

\section{Kondisi Aksesibilitas}

Untuk menuju Kawasan kampung tematik kelurahan cikaret dapat ditempuh dengan menggunakan beberapa moda transportasi baik umum maupun pribadi. Terdapat jalan umum yang dapat dilalui bis berbadan lebar, namun untuk masuk melintasi Kawasan hanya bisa dilalui oleh kendaraan roda empat dan dua, dikarenakan lebar jalan yang relatif sempit (gambar 4).
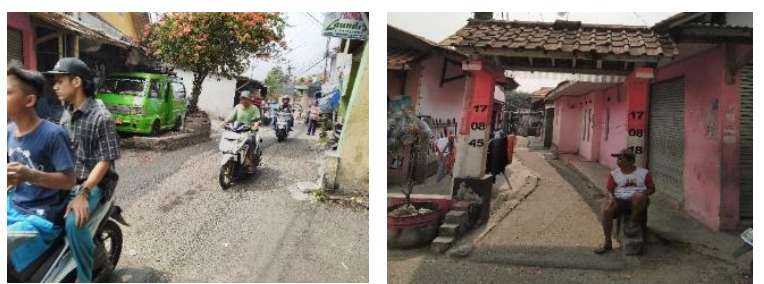

Gambar 4. Kondisi aksesibilitas

\section{Gambaran umum lokasi}

Secara umum gambaran lokasi Kawasan, merupakan Kawasan dengan kondisi perekonomian masyarakat sebagai pedagang dan pengusaha, terdapat budidaya semut kroto di dalam site dengan kondisi sudah sangat memprihatinkan, lokasi berada di Jl. Kapten Yusuf Jl. Raden Kosasih No.3, RT.02/RW.08, Cikaret, Kec. Bogor Sel., Kota Bogor, Jawa. Disekitar site terdapat beberapa vegetasi tanaman dengan tingkatan strata yang berbeda-beda, kondisi jalan utama masih bagus, namun terdapat jalan yang rusak disekitar kawasan permukiman (gambar 5).

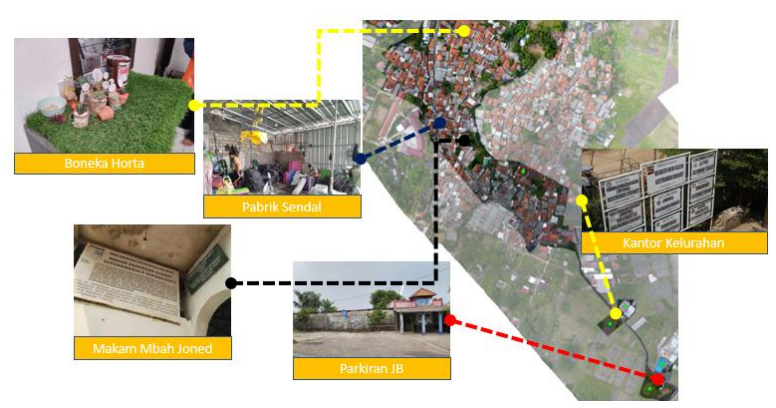

Gambar 5. Gambaran umum lokasi

\section{Potensi Kawasan}

Berdasarkan hasil survei dan FGD (gambar 6) yang dilakukan dengan beberapa perwakilan warga serta dengan dinas terkait (Bidang Pertamanan, PJU, dan Dekorasi Kota, Pemerintah Kota Bogor, dan Kelurahan Cikaret). Terdapat beberapa potensi yang dapat dikembangkan untuk membuat DED Kawasan tematik, diantaranya :

- Untuk Area kroto bond kebutuhan akan ruang aula/ ruang serba guna untuk menampung kegiatan sosialisasi sangat diperlukan. karena menurut sumber, selama ini tidak terdapat tempat untuk menampung tamu/wisatawan.

- Kroto bond bukanlah kegiatan tunggal dikawasan namun dapat menjadi feeder untuk destinasi wisata lainnya di kelurahan cikaret.

- Berdasarkan saran dan masukan dari masyarakat perlu adanya penambahan deliniasi kawasan tematik kelurahan cikaret dikarenakan potensi yang cukup banyak dan tersebar di 4 RW secara garis besar.

- Deliniasi kawasan terbaru terdiri dari 4 RW yaitu RW 07, 08, 10 dan 12 yang sebelumnya hanya sebagian kecil dari RW 07, 08 dan 12 disekitar kroto Bond.
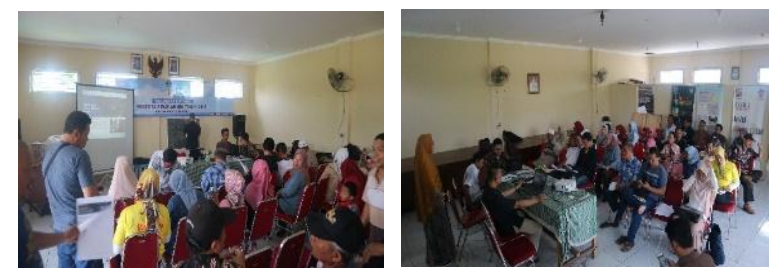

Gambar 6. Forum Group Discussion 


\section{Konsep Pengembangan tapak}

Berdasarkan potensi tersebut maka dibuatlah zoning ruang secara umum. Olahan penataan dan penggunaan ruang dilakukan untuk mendukung kegiatan produksi di Kampung Semut Kroto Kelurahan Cikaret ini dan pada saat yang besamaan juga untuk mendukung program revitalisasi kampung-kota ini. Penataan sirkulasi dalam kawasan kampung ini dilakukan untuk mendukung kegiatan eduwisata semut kroto ini seperti yang terlihat pada diagram konsep pada gambar dibawah ini.

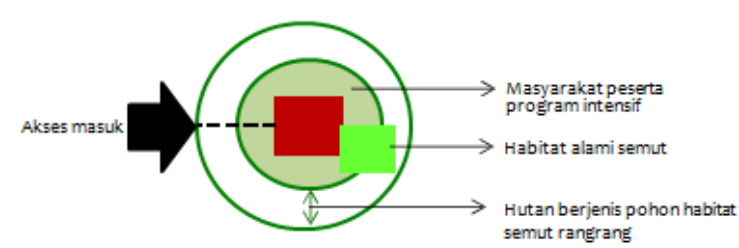

Gambar 7 Diagram Konsep Perencanaan Hasil Rancangan

Setelah melakukan Analisa terhadap Kawasan, baik ruang maupun tapak, maka dibuatlah konsep perencanaan Kawasan kampung tematik. Setelah disetujui dan dilakukan FGD beberapa kali dengan dinas terkait dan masyarakat kelurahan Cikaret maka dibuatlah gambar rancangan dan Detail Engineering Design (DED), yang diharapkan nantinya bisa dimanfaatkan oleh masyarakat sekitar khususnya warga cikaret untuk menata kawasan mereka menjadi lebih baik dan terkenal. Berikut ini adalah beberapa hasil gambar DED yang sudah dibuat (gambar 8).

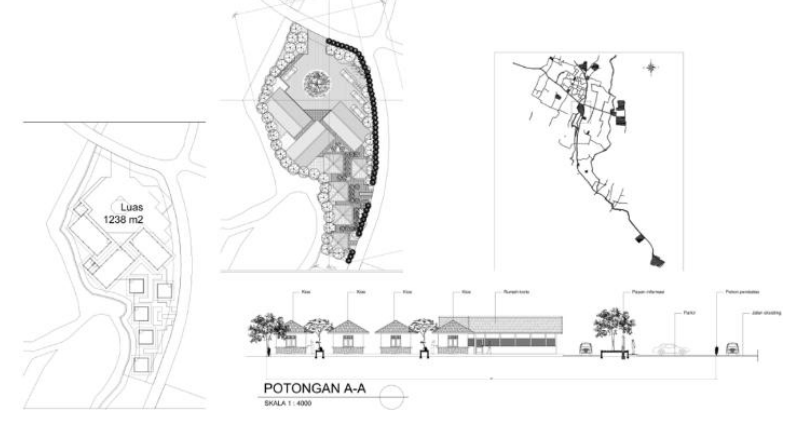

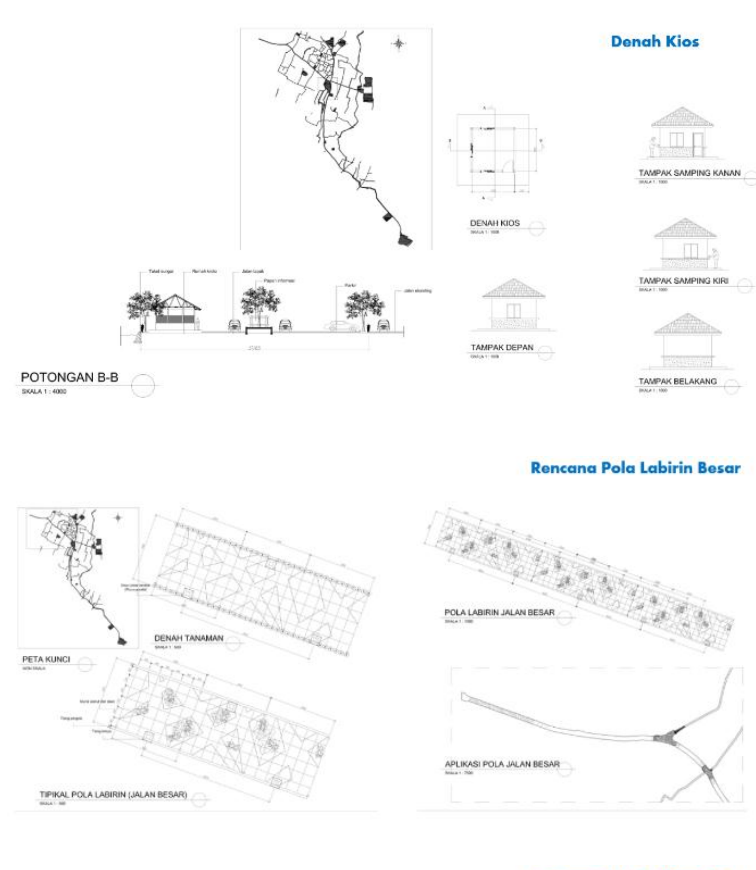

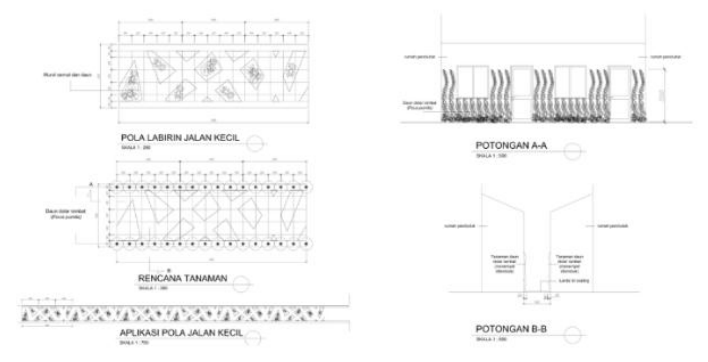

Gambar 8. Hasil Perencanaan

Untuk mempermudah masyarakat memahami bentuk rancangan atau gambaran dari hasil perencanan maka dibuatlah gambaran dalam bentuk 3D (3 dimensi) seperti terlihat pada gambar dibawah ini (gambar 9).
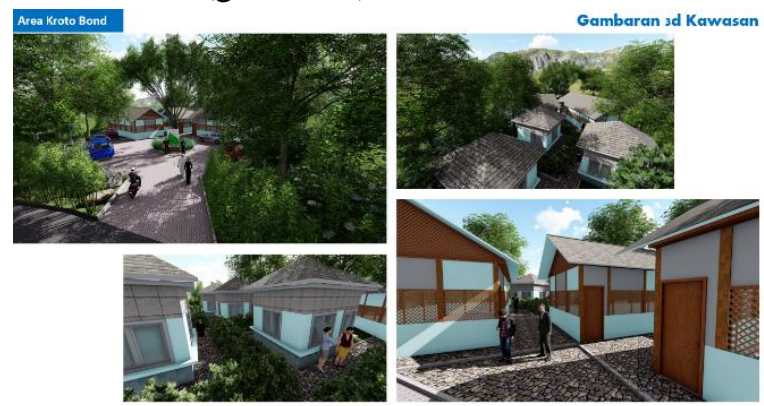

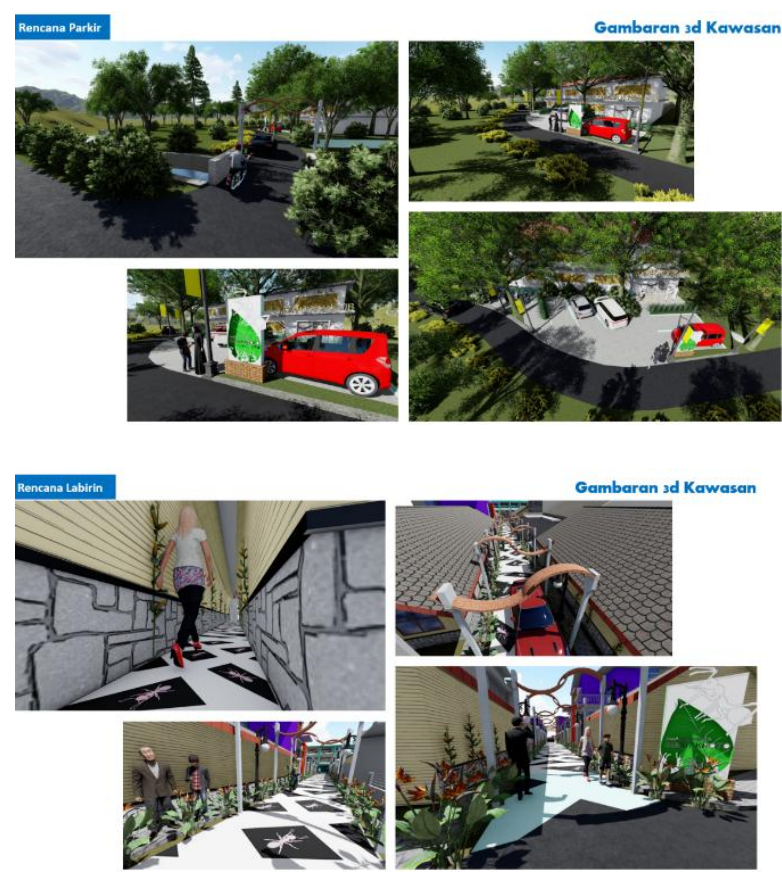

Gambar 9. Visual 3 dimensi

\section{PENUTUP}

Perancangan Kawasan Tematik Kelurahan Cikaret menggunakan metode kualitatif dengan pendekatan desain berbasis komunitas (community based design) yaitu dengan cara melakukan penjaringan persepsi dan keinginan masyarakat. Hal ini dilakukan untuk mengetahui keinginan masyarakat terhadap aktivitas dan fasilitas yang dapat disediakan dan diakomodasi pada tapak.

Konsep Kawasan tematik yang akan direncanakan yaitu Kampung Semut Kroto sebagai destinasi utama dengan beberapa fasilitas dan deliniasi penunjang seperti kampung labirin, hal ini adalah untuk menjalankan usaha berbasis pemberdayaan masyarakat yang diharapkan dapat berdampak terhadap penurunan tingkat pengangguran, juga agar tercipta masyarakat yang mandiri.

Program kegiatan pengabdian kepada masyarakat yang dilakukan oleh staf pengajar dan mahasiswa adalah wujud tridharma perguruang tinggi. Program ini dapat dilanjutkan dengan program pendampingan dari mahasiswa arsitektur dalam kegiatan pembangunan kawasan tematik di Kota Bogor. Selain itu beberapa kawasan yang ada di Kota Bogor yang belum dilakukan perancangannya dapat dijadikan media untuk pengabdian kepada masyarakat dari staf pengajar Program Studi Arsitektur, Universitas Indraprasta PGRI dan mahasiswanya.

\section{DAFTAR PUSTAKA}

Booth, N. K. (1990). Basic Element of Landscape Architectural Design. Waveland Press, Inc.

Hester, R. T., J. (1990). Community Design Primer. Ridge Time Press.

InfoAgribisnis.com. (2017). No Sukses Budidaya Semut Rangrang Penghasil KrotoTitle. Oryza.

Kusumoarto, A., \& Librianti, D. (2018). Desain Taman Lingkungan Permukiman Di Kota Bogor Berbasis Aktivitas Komunitas. 99108.

Motloch, J. L. (2001). Introduction to Landscape Design. John Wiley \& Sons Inc. 